\title{
Erratum to: Renewal of extinguished instrumental responses: independence from Pavlovian processes and dependence on outcome value
}

\author{
Sabrina R. Cohen-Hatton ${ }^{1}$ - R. C. Honey ${ }^{1}$
}

Published online: 17 August 2016

(C) Psychonomic Society, Inc. 2016

Erratum to: Learn Behav (2013) 41:379-389

DOI: $10.3758 / \mathbf{s} 13420-013-0113-y$

On page 379, in the last three lines of the Abstract, "inhibition" is misspelled as "inhibion", "association" as "associaon", and "potential" as "potenal". Springer regrets these errors, which were introduced postproof.

The online version of the original article can be at http://dx.doi. org/10.3758/s13420-013-0113-y.

$\triangle$ R. C. Honey

Honey@cardiff.ac.uk

1 School of Psychology, Cardiff University, Tower Building, Park

Place, Cardiff CF10 3AT, UK 